\title{
The Ancient Physician: Craftsman or Scientist?
}

\author{
H.F.J. HORSTMANSHOFF
}

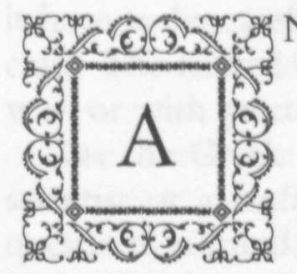

CIENT physicians did not receive scholarly, scientific training. The intellectual attitudes and social status which we are inclined to attribute to them are anachronisms nourished by the Hippocratic tradition from Galen to Littré. Physicians who had scholarly ambitions steered toward philosophy and rhetoric rather than to empirical disciplines. As a consequence of the prevailing social and economic outlook, the image of the rhetor and of the philosopher were considered to be far better than that of the engineer or of the artisan, or that of those devoted to applied knowledge in general. Ancient physicians were above all craftsmen. Nevertheless the more ambitious among them cloaked over the manual aspects of their art and explained away the remuneration for their services with the help of rhetoric.

\section{INTRODUCTION}

Athens, about 400 B.c. Two physicians are discussing a patient in a language now deemed "dead." We can catch a few words: ... arthritis, ... rheumatism, . . . crisis, . . prognosis, . . asthma, . . tetanus, . . anthrax, $\ldots d y$ sentery, ... pleuritis, ... hypochondria,$\ldots$ anatom $y, \ldots$ epidemic .... All these terms belong to today's normal medical usage; they are words

This translation of "De antieke arts: ambachtsman of man van wetenschap?," Lampas 20: 340-55, I987, was done by Dr. Ernst J. Brehm of Creighton University. Dr. Bruce J. Malina, also of Creighton, edited the Greek, while the author revised and edited the final draft. The author wishes to thank John Scarborough, University of Wisconsin, who encouraged the realization of the English version of this article, and both "translators," who by their acumen and helpful criticism contributed considerably to a clearer wording of the original text. Of course, the author remains responsible for the text as it stands.

(C) I990 BY THE JOURNAL OF THE HISTORY OF MEDICINE AND ALLIED SCIENCES, INC. ISSN $0022-5045$ 
still recognized as Greek terms. We get the feeling of standing at the cradle of Western medical science. ${ }^{1}$

How well-founded is this impression? Is our recognition of the words illusory? Did Greek physicians mean the same things we do with all of these terms? Were they scientific terms in their day?

By "science" here I mean empirical science, that human activity which is directed to the acquisition of knowledge, and whose characteristic features are accurately describing, categorizing, registering, understanding, explaining, and predicting, with the ultimate purpose of controlling, hence of influencing processes. Scientific learning and behavior based on it have to be carefully distinguished from training in and practice of a craft. The latter look to the performance of certain actions in a better way, or with greater results, or more quickly. ${ }^{2}$

Was the Greek physician who used the words mentioned above a scientist or a craftsman, a scholar or an artisan? With the foregoing questions in mind, we shall give closer scrutiny to two of those terms: epidemic and prognosis.

\section{EPIDEMIC}

The Greek epidemia did not mean what our term "epidemic" means today. The noun "epidemic" refers to "an outbreak of epidemic disease," a disease "affecting or tending to affect many individuals within a population, community or region at the same time" (Webster's Ninth New Collegiate Dictionary). The Greek adjective epidemios means: "confined to a certain people," "indigenous," "characteristic of a certain region."

Epidemiai is the title of one of the writings attributed to Hippocrates. In free translation, the term essentially means "observations made while traveling among certain people," or "stories about certain sick people," i.e., "case histories." The writing in question consists of a description of the climate, terrain, landscape, and of the sicknesses that were characteristic of a certain region, and which a physician who regularly traveled the region could observe during a visit. Books I and III of the Epidemics date to the fifth century B.C. and are quite possibly the work of Hippocrates himself or derive from his immediate followers.

I. In the vein of the ancient Greeks and Romans who regarded imitation and emulation as the highest forms of praise, with this opening sentence I pay tribute to Guido Majno's ever stimulating work, The Healing Hand, Cambridge, Massachusetts, Harvard University Press, 1975; see p. I4I.

2. Cf. Adrianus D. de Groot, Methodologie. Grondslagen van onderzoek en denken in de gedragswetenschappen, 8th ed., Den Haag, Mouton, 1975, p. 19, and H. A. Becker, Sociale Methodologie. Inleiding tot de werkwijze van de sociale wetenschappen, third ed. Meppel, Boom, I979, pp. Is $\mathrm{ff}$. 
Let us read one of these "case histories" (Epidemics III, I, 6, Loeb pp. $228-31):$

The unmarried daughter of Euryanax took a fever. She suffered from no thirst throughout and did not take her food. Passed small stools; the urine thin, of small quantity and not of good color. At the beginning of the fever she had pain around the anus. On the sixth day she did not sweat, as she was without fever, and reached a crisis. However, there was some slight suppuration about the anus, the abscess bursting about the time of the crisis. On the seventh day after the crisis rigors occurred and there was slight fever with sweating. Subsequently she was always cold about the extremities. About the tenth day after the sweating occurred, she became delirious, but quickly recovered her lucidity again. They said it was through eating grapes. After an intermission of twelve days, she again became quite delirious, the bowels were disordered, the stools being bilious, unmixed, small in quantity, thin and pungent. The stools were passed frequently. She died on the seventh day following the last attack of her illness and a rash was present throughout, while the uvula was retracted. Fluxes were present, small and acrid. Although she had a cough it was unproductive. She had no appetite the whole time, nor did she wish for anything. She had no thirst and drank nothing worth mentioning. She was silent and would not talk. She was depressed and despaired of herself. There was also some sign of an inherited tendency to consumption (trans. J. Chadwick and W. N. Mann, Hippocratic Writings, N.Y.: Penguin 1978, pp. 117-18).

In comparison with modern medicine, what were the scientific features of Hippocratic medicine?

First of all, what draws attention in the foregoing description is the exact observation not only of physical phenomena (fever, stool), but also of psychological features (hallucinations, depression). The patient's symptoms are observed daily and recorded in brief, objective style, on a writing tablet (Epidemics VI 8, 7). A Greek physician trained in the Hippocratic school was able to make quite exact observations. He listened to a patient's breathing with his ear against the patient's back. He felt the temperature of the various parts of the body and palpated the abdomen. He checked the odor of all sorts of secretions: the stool, urine, phlegm, vomit; he noted their color and according to the Hippocratic writings, would even test the taste of these items (Epidemics IV 43), something that must have required a good deal of self-control. Such precise examination, which involved switching on all the sense organs, surely belonged to the strong side of Hippocratic medicine. Such observations were certainly theory-based, but were they scholarly and scien- 
tific to the extent that their ultimate purpose was to control, even influence biological processes?

The philosophical traditions of the time furnished the theoretical background with a doctrine of the four bodily humors (phlegm, black bile, blood, yellow bile), which related to Empedocles' teaching on the four elements (water, earth, air, fire) and the two fundamental pairs of opposites (cold-warm and dry-moist). In the course of centuries, this scheme developed into a universal system that eventually embraced the four points of the compass, the four seasons and four sets, of three each, of the Christian apostles. ${ }^{3}$ Sickness is explained as a disturbance (dyskrasia) of the proper balance among the four body humors. As symptoms of such disturbance, all sorts of secretions were considered, as for instance urine, sweat, and the like. The physician sought to restore the proper balance by prescribing some rules for living (diaitai). The Hippocratic physician considered nature as the best healing power; he regarded medications with skepticism.

In comparison with modern medicine, then, what is missing from the previously cited case history from Hippocrates' Epidemics? We get the distinct impression that the physician did not prescribe any medications, that he did not actually treat anything. The description of the sickness lacks any diagnosis, any determination of the type of affliction, as well as any therapy. Furthermore, it lacks the whole scientific apparatus at the disposal of the modern physician for both diagnosis as well as for therapy. There were no thermometers, no X-ray equipment, no laboratory tests, none of the products of the pharmaceutical industry. What the Hippocratic physician did was observe and describe well. Are these features sufficient to call him a medical scholar, a man of science? In order to answer this question, it is necessary to discern the purpose of those observations. This purpose is called prognosis.

\section{PROGNOSIS}

In the case history just recounted, the patient died. This is what happened in $60 \%$ of the cases presented in the Epidemics. The physician obviously did not take any trouble to hide this fact, so why are all of these cases recorded in such detail? Prosopographical studies of the personages mentioned in the Epidemics make it evident that we are not dealing with

3. Antje Krug, Heilkunst und Heillkult: Medizin in der Antike, Munich, C. H. Beck, 1985, p. 48. 
fictitious accounts of disease but with historically verifiable patients. ${ }^{4}$ Hence one can rightfully call these case histories.

An indication of the purpose of this sort of small-scale historiography can be found on a large scale in the work of the historian Thucydides. He set forth the motive behind his describing the Athenian plague of $430 / 429$ B. C. as follows: "But I shall describe its actual course: explaining the symptoms, from the study of which a person should be best able, having knowledge of it beforehand, to recognize it if it should ever break out again" (II 48, Loeb pp. 343-45). Similarly, he presented his history of the Peloponnesian War in order that future statesmen might have the benefit of his description (I 22). The benefit did not consist in the greater control of events - in this sense Thucydides was no optimistbut rather in the mental preparedness afforded by reliable information concerning cautionary symptoms. ${ }^{5}$ Thucydides wrote for statesmen. With a similar goal in mind, the Hippocratic physician recorded symptoms on his writing tablet for his peers. The Epidemics were presumably destined primarily for an audience of colleagues and were to serve as a basis for prognosis. ${ }^{6}$ The Hippocratics, of course, knew about diagnosis and therapy, and they applied their knowledge, as is abundantly testified in the Hippocratic writings. Still these aspects were not the primary aims of the Epidemics.

It is precisely prognosis that is most often regarded as the hallmark of the scientific orientation of Hippocratic medicine. Prognosis distinguished it from raw empiricism, i.e., empiricism without a full theoretical basis, on the one hand, and from blind speculation on the other. This was noted already by Émile Littré in the first part of his Oeuvres complète d'Hippocrate $(\mathrm{I}, 454)$, published in 1839 and still the only complete edition of the Corpus Hippocraticum.

Hippocratic prognosis seems quite modern and scholarly, but behind it stood a social reality that differed greatly from that of today. When we think of a physician today, we imagine a scientifically educated prac-

4. Karl Deichgräber, Die Patienten des Hippokrates: Historisch-prosopographische Beiträge zu den Epidemien des Corpus Hippocraticum, Wiesbaden, Franz Steiner Verlag, 1982, Abhandlungen der Academie der Wissenschaften Mainz, No. 9.

5. W. Robert Connor, Thucydides, Princeton, New Jersey, Princeton University Press, I984, p. 3I. Concerning points of contact between Thucydides and the healing arts of his time, H.F.J. Horstmanshoff, Die Pijlen van de Pest. Pestilenties in de Griekse Wereld (800-40o v.C.), thesis Leiden, Amsterdam, r989, pp. 2 I I-I9.

6. The question concerning the reading public for which Epid. I and III were written has been treated by Rainer Hellweg, Stilistische Untersuchungen zu den Krankengeschichten der Epidemienbücher I und III des Corpus Hippocraticum, Bonn, Rudolf Habelt GmBH, 1985, pp. 230-36. 
titioner of a legitimate profession of high social status. This image of the physician emerged only in the second half of the nineteenth century. On the contrary, the physician of antiquity did not belong to a legitimate profession, protected by legal and official recognition. For the most part he lacked scholarly, "academic" training, and he did not always enjoy a high social status. ${ }^{7} \mathrm{He}$ had to compete with quacks and miracle workers; he could not afford to risk his reputation by treating patients who had no chance of recovery. In I93 I Edelstein noted that the important role played by prognosis in the Corpus Hippocraticum had to be explained as motivated by occupational concerns rather than by scientific ones. ${ }^{8} \mathrm{~A}$ precise prognosis was necessary in order to enable the physician to disclaim responsibility in fatal cases. Prognosis was also the means the physician employed to win the trust of patients so that they might put themselves in his care. For with prognosis, the physician could skillfully fill in the "silences" during the patient's recounting of what was bothering him or her (anamnesis). Prognosis thus covered the total course of the sickness, its past, present, and future!

The Hippocratic writing, Prognostikon, stated the following: "I hold that it is an excellect thing for a physician to practice forecasting. For if he discover and declare unaided by the side of his patients the present, the past and the future, and fill in the gaps in the account given by the sick, he will be the more believed to understand the cases, so that men will confidently entrust themselves to him for treatment" (Prognostic I, Loeb pp. 6-7). Albert Schweitzer's experience in Africa confirmed this: "For in the opinion of the Black Africans the efficacy of medicine is demonstrated primarily in that the physician knows whether the patient will die or not, and in that the physician does not apply his art to someone who is really already dead. Should he treat someone who later dies under his care, that only shows that he does not yet know whether a given illness is mortal or whether it can be healed." 9

Prognosis was a rhetorical form with psychological effect. The patient was to experience his or her prognosis as a sort of prophecy. The border-

7. Cf. Abram de Swaan, De mens is de mens een zorg, 3rd ed., Amsterdam, 1984, pp. 5I-23 I; see now his In Care of the State: Health Care, Education and Welfare in Europe and the U.S.A. in the Modern Era, New York, Oxford University Press, 1988; Edward Shorter, Beside Manners: The Troubled History of Doctors and Patients, New York, Simon and Schuster, I986; J. Kollesch, “Ärztliche Ausbildung in der Antike," Klio 6: 507-13, 1979.

8. Ludwig Edelstein, "Hippocratic Prognosis," in Ancient Medicine, Baltimore, Maryland, The Johns Hopkins Press, 1967, pp. 65-85.

9. Albert Schweitzer, Briefe aus Lambarene 1924-1927. Gesammelte Werke I, Munich, C. H. Beck, 1974, p. 519. 
line between rational and irrational medicine was not sharply drawn. There were priests who furnished medicines and dietary regulations and who performed bloodletting, just as there were physicians who used amulets and prayers.

The physician found due recognition for his healing art when he was able to announce his abilities through rhetorical means. Hence besides being a craftsman, he had to be a rhetor. The physician likewise needed rhetoric in his search for employment as a city physician (iatros demosios or demosieuon). Such employment was awarded by the city council or by the city public assembly (cf. Plato, Gorgias $455 \mathrm{~B}$ and Xenophon, Mem. IV 2,5). The members of these bodies were more impressed by a stirring argument about health and sickness and by a good show than by medical technique as such. In second century A.D. Ephesus, for an audience keen on effect, physicians had to prove their competence by engaging in mutual competition in "chirurgy," "instrumentation," "problem solving," and "composition." I find it hard to avoid the impression that in all four events bombastic, ranting speech-making won the day. ${ }^{10}$

The exact observation of sicknesses and the recording of them in case histories (epidemiai) along with prognosis, when considered from a modern point of view, speak for the scholarly, sicentific character of ancient medicine. However, those features can in fact be traced back to the social position of the physician as craftsman. For when viewed from the standpoint of antiquity, the physician's scholarly pretensions move rather in the direction of philosophy (humoral theory) and of rhetoric (prognosis) than in the direction of the natural sciences and their application. The practitioner seemed far less intent upon the manual, craftlike features of medicine than upon the rhetorical, philosophic aspects.

THE HIPPOCRATIC TRADITION

From where does the image of Hippocrates as founder of scientific medicine actually derive?

When Émile Littré published the first part of his Oeuvres complètes d'Hippocrate in 1839 , the development of medicine had reached an impasse. While it is true that technical knowledge about surgery had increased considerably at the beginning of the nineteenth century, yet the danger of infection lurked everywhere. Routine operations could hardly be performed and medicines appeared to be largely ineffective. The only

10. For the epigraphical evidence, see Die Inschriften von Ephesos Teil IV, Bonn, Rudolf Habelt $\mathrm{GmBH}$, I980, numbers I I6I-I 63 . 
way out of the difficulty seemed to be a return to the sources of medical learning. In those sources, the exact observation of cases of illness was the hallmark of several Hippocratic writings, justifiably warranting their fame. This feature appealed to those Parisian physicians averse to dogmatism and often engaged in political activity-Littré had participated in the street fighting of the July Revolution of 1830 .

It is against this background that we must assess Littré's decision to place at his colleagues' disposal a new edition of the Greek Corpus Hippocraticum with facing French translation. However, by the time the tenth and final part of the Corpus Hippocraticum had been published in I 86I and Littré's life work had been fulfilled, the aforementioned impasse seemed to have been broken. In 1858 Virchow came out with his trail-blazing Cellular Pathology, while a few years later Lister laid the foundation for antiseptic surgery. Thus the Corpus Hippocraticum was banished from the physician's consulting room to the libraries of historians and classicists, and freed at the same time from the grip of classicism. Littré was the last interpreter for whom Hippocrates served as a living model, relevant for daily practice. It was only now that the ancient physician could be studied within the framework of his own age, just as Homer could be scientifically studied only after F. A. Wolf's Prolegomena ad Homerum (I795). After mathematics, mechanics, and philology, medicine too was emancipated from classicism. ${ }^{11}$

This train of events has been of decisive influence on the image of Hippocrates as founder of scientific medicine, an image certainly still in vogue today outside a small circle of specialists in the history of ancient medicine. According to that traditional image, Hippocrates of Cos (c. $460-370$ B. C.) already used the experimental method in the same way as modern scientists do (Littré I, 463). Characteristics of the former would be: emphasis on the patient rather than on the disease; stress on observation rather than on theory; and the great value attributed to prognosis. Writings in the Corpus Hippocraticum which matched this image of the "scientific" Hippocrates were given the label "authentic," while the rest of the writings, often for quite arbitrary reasons, were designated as "not genuine." However, scholars often do not inquire about what the term "authentic" really refers to. Must the writing have been written by Hippocrates himself? By his school?

In his book, The Hippocratic Tradition (1979), the classics scholar, Wes-

II. Cf. C.M.J. Sicking, "Classici(sten)," Lampas 11: 183 ff., 1978. 
ley D. Smith, traced the trail of the Hippocratic tradition as far back as possible. Smith convincingly pointed out that while Enlightenment thinking branded clerics, tyrants, and philosophical speculation as enemies of human advancement, it considered the source of progress to be human reason alone when applied to the disciplined observation of nature. It was Enlightenment thinking which probably set its own stamp of approval on the Hippocratic tradition. Since Hippocrates was considered the founder of scientific medicine, everything in the Corpus Hippocraticum not in conformity with the highly idealized image of the "scientific" Hippocrates, the first person deserving of the name "physician," had to be judged as the outcome of some corruption of the master's thought. Clearly this image of Hippocrates was not the result of historical research, but of the prevailing scholarly interest of physicians of the day. And this image was further fostered by historians and philologians of the period. They provided the "proof," so assiduously sought after, of the "scientific" attitude of Hippocrates. In this way, according to Smith, the history of medicine at the time of Hippocrates became an etiological myth, an analytical scheme in the form of a historical narrative. ${ }^{12}$

However, it was not only Littré, and before him, Boerhaave, Sydenham, and Paracelsus who projected their own ideals upon the Corpus Hippocraticum. The contribution of Galen (c. I29-I95 A.D.) was of decisive importance. Through his unbelievable productivity as a writer, he was to exercise enormous influence that would stand firm through fourteen centuries. It was the manner in which Galen utilized the Hippocratic writings that strongly promoted the preservation of the Hippocratic myth. Galen looked for support in the Corpus for all his opinions, even for changes in those opinions. Just before Galen's time, a first canonized edition of the Corpus appeared. Throughout the various polemics in which he became involved, he did not fight his enemies directly, but rather accused them of attacking Hippocrates, even if they said nothing about Hippocrates. This procedure resulted in a much distorted picture of the history of medicine in antiquity. Galen created the impression that all physicians before him had been either followers or opponents of Hippocrates, and therefore that Hippocrates was the norm by which all had to be measured.

In order to be able to understand this, it is necessary to underscore the social factors involved even more forcefully than Smith did. Galen stood

\footnotetext{
12. Wesley D. Smith, The Hippocratic Tradition, Ithaca, New York, Cornell University Press, 1979, p. 30.
} 
in the rhetorical, philosophic tradition. His education bore the brand it did quite in conformity with the educational ideals of his age. An imperial edict of 93 or 94 (M. McCrum and A. G. Woodhead [eds.] Select Documents of the Principate of the Flavian Emperors A.D. 68-96, Cambridge, Cambridge University Press, I96r, no. 458) relates that rhetors and physicians alike were granted freedom from taxation. Under subsequent emperors as well, grammarians, rhetors, philosophers, and physicians were considered a group comprising a homogeneous profession.

Professional titles such as iatrophilosophos and iatrosophistes attest to this homogeneity. Medicine enjoyed less prestige as a craft than it did as a subset of rhetoric. Through his education Galen was steeped in the various versions of the Hippocratism of his teachers. A continuous esoteric exegesis of Hippocratic texts had familiarized him with the practice of tracing back the essential features of the medicine of his own day to the Corpus. In the second century A.D. conflicts among famous sophists were the occasion of great public excitement; even emperors got involved. Complaints about the body and spirit kept the minds of the time just as busy. Anyone reading Aelius Aristides and Fronto cannot help thinking that these gentlemen truly enjoyed their poor health. Now Galen combined ability as a physician with sophistic brilliance and an acquired reputation as a "lion of society" in higher Roman circles. These traits adequately explain his popularity. ${ }^{13}$

The collection of medical writings now known as the Corpus Hippocraticum was gathered from various sources in Alexandria at the close of the third century в.с. The empiricist school of medicine attached great value to the authority of the Corpus. The empiricists were skeptical about theoretical disquisitions and philosophical investigations. They confined themselves to actual observations and drew conclusions from analogous cases. In their altercation with the dogmatists (ca. 250-100 B.C.), they were elated to notice that "Hippocrates" preferred observation to abstract theory formulation. Galen himself developed from the empiricist position to the dogmatic, influenced by the various types of Hippocratism of his teachers. It was Galen who made Hippocrates the "Father of Medicine."

The Corpus Hippocraticum emerged between c. 450 and 350 B.c. It

13. About Galen as a sophist, see Glen W. Bowersock, Greek Sophists in the Roman Empire, Oxford, The Clarendon Press, 1969, pp. 59 ff., and J. Kollesch, "Galen und die Zweite Sophistik," in Galen: Problems and Prospects, ed. Vivian Nutton, London, Wellcome Institute for the History of Medicine, I98I, pp. I-I I. 
certainly is not the product of a single author. Along with clinical observations emphasizing the value of prognosis based on symptoms, this collection of writings also contains schematic catalogues of sicknesses. These various writings do not all share the same theoretical perspective. For his interpretation, steeped in Enlightenment thinking as he was, Littré employed precisely those writings that Galen did not use. It is an irony of history that by beginning his reconstruction of Hippocratic medicine with the work, Concerning Ancient Medicine, Littré deviated from Galen's viewpoint. He thought that by choosing this starting point he was locking on to the Hippocratism of the fifth and fourth centuries B. C. Yet in reality Littré reconstructed the outlook of the Alexandrian empiricists with whom the Hippocratic tradition started! For there is no evidence from the fourth century B.C. for physicians' recognizing Hippocrates as an authority.

Thus the image of Hippocrates as founder of "scientific" medicine is a product of rather recent, Enlightenment thought. Should one wish to label ancient medicine as "scientific," the term "science" will have to be furnished with a content different from the one defined above. It was not medicine as craft that enjoyed the prestige of "science," but rather medicine as rhetorical, philosophic speculation about sickness and health that received the accolade. Celsus, the Roman author of De Medicina (first century A.D.), praised Hippocrates for separating medicine from philosophy (Prooem. 8). Yet the opposite view of the matter is more consonant with reality - the practitioner of the craft of healing sought affinity to philosophy motivated by his craft. If he wished to expand his medical knowledge beyond the confines of empiricism, he had to borrow a theoretical framework from philosophy. If as a craftsman he wished to acquire social prestige, he had to don the philosopher's mantle. ${ }^{14}$

However the foregoing considerations do not imply that we can simply shove Hippocratic medicine aside as a myth. Rather it was specifically as reflection upon the craft of healing that it had contributed so much to the development of modern scientific thinking. The famous writing, Concerning the Sacred Disease, directed its attack not just against some forms of superstition, but against all forms. The precise observations of concrete cases of sickness surely strongly deviated from the way in which Greek philosophers commonly attempted to explain nature, that is with eyes closed. And finally, recall the everlasting contribution of Hippocratic

14. O. Temkin, "Greek Medicine as Science and Craft," Isis 44: 21 3-25, 1953, reprinted in Antike Medizin, ed. H. Flashar, Darmstadt, Wissenschaftliche Buchgesellschaft, I970 pp. 1-28. 
medicine to medical ethics. To be sure, the duty of secrecy, the promise to apply medical knowledge only to heal and not to harm, and the refusal to cooperate in abortion and euthanasia were not subscribed to by all physicians in antiquity, not even by all Hippocratic physicians, but only by a minority. Craftsmen's motives, such as the fear of losing one's reputation, also played a part. ${ }^{15}$ The Hippocratic physician constantly invested in his reputation, since with a good reputation he would not repeatedly have to demonstrate his competence, especially in the continual competitive battles waged with physicians of quite different alloy. ${ }^{16}$ But the fact remains that in this way a norm was established, and it still remains, even though this strict code of honor was and is not subscribed to nor emulated by all physicians.

\section{THE SOCIAL STATUS OF THE PHYSICIAN}

"Everything is related to money. It would be a pity if my profession were exercised with finances in the back of the mind," declared an orthopedic surgeon in an interview in a Dutch newspaper (NCR-Handelsblad, 7 February 1986).

"I always keep money apart from my relations with patients. I do not check whether a person who comes to me has paid his bill," said an internist in the same newspaper, 4 February 1986.

To hear such comments, it would seem money plays no part, at least for a gentleman. At times one hits upon a fine bit of ideology. A specialist says right up front that he lives simply; he leases a small Mercedes, "a car costing 45, ooo guilders (about $\$ 20,000$ ) is adequate for me" (NCRHandelsblad, 8 February I986).

The campaign, begun in 1986 , by physicians belonging to the National Specialists' Union in the Netherlands has served to contribute to the long persistent discussion about what actually is the social standing of the physician. Is he a craftsman who without batting an eyelash regularly demands money for his services, or is he a scholarly intellectual of high social standing for whom the pedestrian concern for payment plays no part, at least publicly?

The two divergent viewpoints are already noticeable in the Homeric

15. Edelstein, (n. 8) "The Hippocratic Oath," in Ancient Medicine, pp. 3-63. Cf. G.E.R. Lloyd, Science and Morality in Greco-Roman Antiquity, Cambridge, Cambridge University Press, 1985; I thank W. Jongman for the reference.

I6. Edelstein, (n. 8) "The Professional Ethics of the Greek Physician," in Ancient Medicine, pp. 319-48. 
poems. In the Iliad (IX 5 I4-5I 5 ; Loeb 5 I 9 with alterations) we read: "For the gentleman practitioner is of the worth of many other men for the cutting out of arrows and the spreading of soothing medicaments!" The Greek word ietros is here translated "gentleman practitioner" because the term refers to those "gentlemen" who rushed forward when in the Iliad a warrior, God or man, was wounded in battle. Machaon removed the arrow that hit Menelaos (Iliad IV 213). Paieon, who only treats gods, puts pain-killing medication on Ares' wounds (Iliad V 899-906). Although most warriors in the Iliad demonstrate adequate medical knowledge for the elementary treatment of wounds, some are regarded as more knowledgeable than others. They are called ietroi, physicians. The most eminent are Podalirius and Machaon, the sons of Asclepius. They straddle the fine line between professionalism and amateurism. They themselves belong to the category of elite warriors, but through their medical knowledge they occupy a special position. In any case, they did not have to work for pay.

Another type of physician is described in the Odyssey. There physicians are listed along with seers, carpenters, and troubadours, as traveling demioergoi, i.e., "those who act for the well-being of the people" (Odyssey XVIII 383 and ff.). Eumaios speaks to Antinoös who reproaches him for having admitted a beggar (Odysseus in disguise) into the palace: "Who, pray, of himself ever seeks out and bids a stranger from abroad, unless it be one of those that are masters of some public craft: a prophet, or a healer of ills, or a builder, aye, or a divine minstrel who gives delight with his song? For these men are bidden all over the boundless earth" (Odyssey XVII 383-387, Loeb 179).

The word demioergos is the same as demiourgos, and the latter is used for "craftsman, artisan." There is no reference here to amateurs, but to "professionals," manual workmen who do not belong to the noble elites, but neither do they belong to the thetes, the landless manual laborers. Such specialists in an otherwise scarcely professionalized society floated between both extremes of the social hierarchy. ${ }^{17}$ It is possible that both types of physicians developed successively, the nonelite practitioner after the elite. Yet it is equally possible, however, that they emerged alongside each other within the same society as two types of physicians: the man of prestige and noble descent and the practitioner of the "craft" with the status of "craftsman." There are indications that this latter view is correct.

17. Moses I. Finley, The World of Odysseus, New York, Viking Press, 1988, pp. 37, 55-6. 
According to Pleket, ${ }^{18}$ both of these lines, that of the craftsman-like demiourgos and that of the noble amateur, can be traced down to the Greek polis society of Roman Imperial times. The former worked for their sustenance, often traveling from city to city; they were not poor, but neither did they belong to the city elite. The latter too obtained income from their profession, but suppressed all mention of it for ideological reasons. They were the men of learning, the intellectuals, who formulated their pursuits in rhetorical terms.

Throughout all of antiquity, the Mediterranean world must have witnessed a parade of quacks and charlatans, miracle workers and surgeons, as well as physicians with the status of craftsmen who moved from one city to another in search of work. How far their travels could take them is evident from the inscriptions that have been unearthed. As indicated by his tomb inscription, a certain Hedys, a physician during Imperial times, saw "the currents of Okeanos and the limits of Europa, Libia and the great Asia." 19

The most desirable position for a physician was that of city or community physician: ho demosios iatros. The city physician enjoyed public recognition and, probably, a fixed minimum income by virtue of a contract through which he was obliged to remain in a given city for a number of years. The advantage for the physician was that he no longer had to contend with other physicians in competitive forays. The advantage for the city was that it could be assured of medical services. The British epigrapher, A. G. Woodhead, in a 1952 article, ${ }^{20}$ concluded that in the Greek world of classical and Hellenistic times, there must have existed a "state health service," a "National Health Service," ahead of its times, offering the citizens of a city free health care from a physician employed by the city. However later investigators ${ }^{21}$ have emphasized that Woodhead's conclusion was incorrect. For while it is true that in the

18. H. W. Pleket, "Arts en maatschappij in het oude Griekenland. De sociale status van de arts," Tijdschrift voor Geschiedenis, 96: 325-47, 1983.

19. L. Robert, Hellenica 11: 103-8, 1946, reprinted in Inschriften der Griechen: epigraphische Quellen zur Geschichte der antiken Medizin. ed. Gerhard Pfohl, Darmstadt, Wissenschaftliche Buchgesellschaft, 1977, pp. 79-87.

20. A. G. Woodhead, "The State Health Service in Ancient Greece," Cambridge Historical Journal 10: $235-53$, 1952, reprinted in (n. 19) Inschriften, ed. Pfohl, pp. $31-65$.

2I. Esp. L. Cohn-Haft, The Public Physicians of Ancient Greece, Northampton, Massachusetts, Department of History, Smith College, I956 and Vivian Nutton, "Continuity or Rediscovery: The City Physician in Classical Antiquity and Medieval Italy," The Town and State Physician in Europe from the Middle Ages to the Enlightenment, ed. Andrew W. Russell, Wolfenbüttel, Herzog August Bibliothek, 198I, pp. 9-46. 
Athens of the fifth century B.C. there were certified city physicians and that epigraphical evidence about physicians during the Hellenistic Roman period has increased greatly, yet not a single text indicates that a city physician was obliged to give free treatment.

An example that can be matched by many others ${ }^{22}$ clearly shows what position the city physician occupied in Hellenistic times. The following inscription was found in Gytheion (Laconia), in honor of the Spartan physician, Damiadas (IG V I I 45, c. 7 O B.C.):

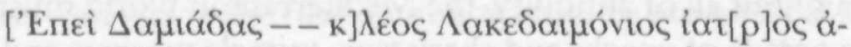

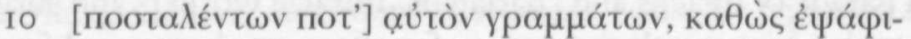

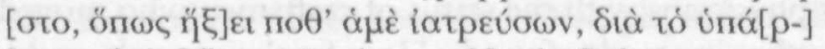

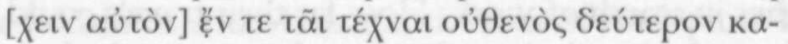

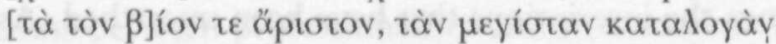

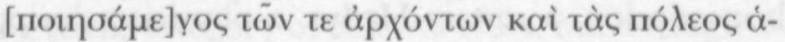

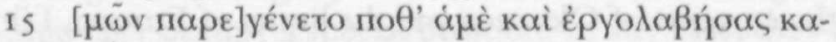

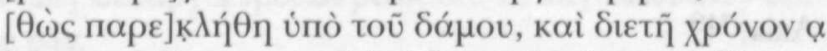

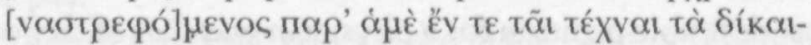

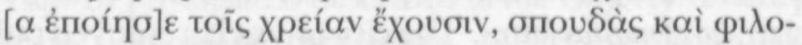

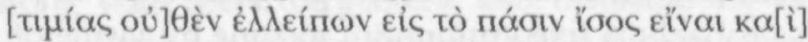

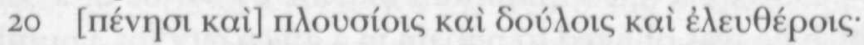

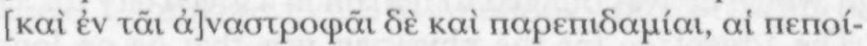

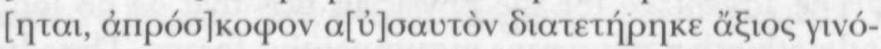

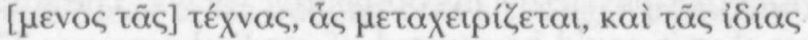

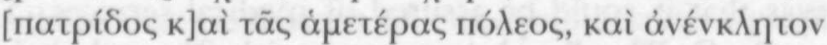

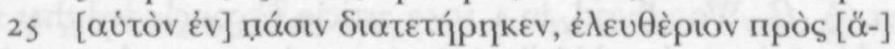

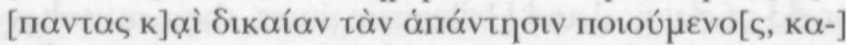

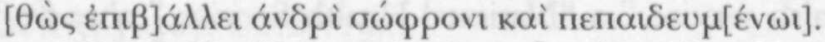

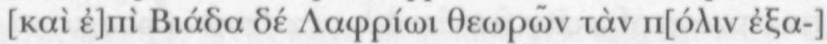

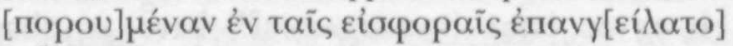

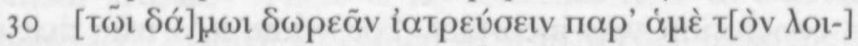

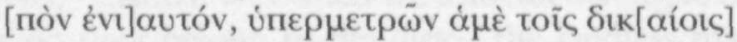

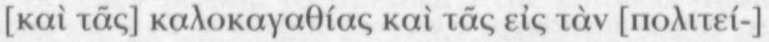

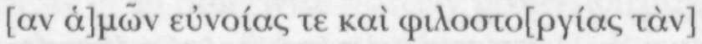

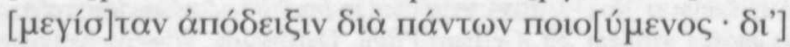

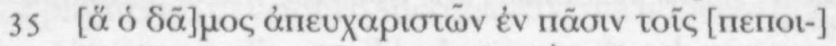

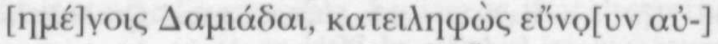

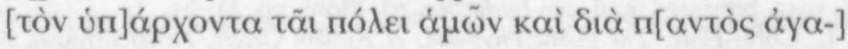




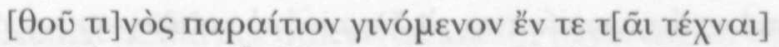

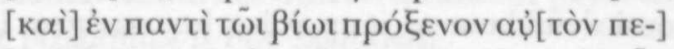

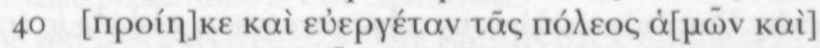

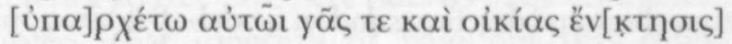

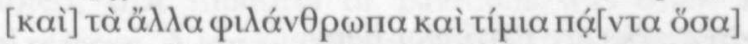

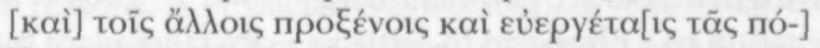

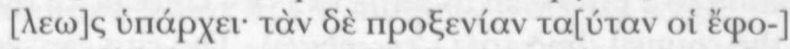

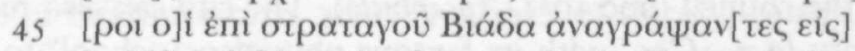

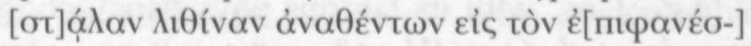

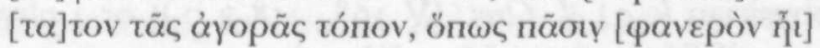

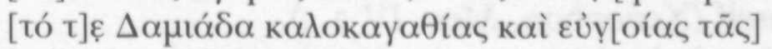

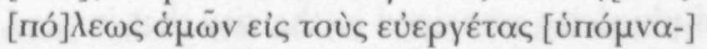

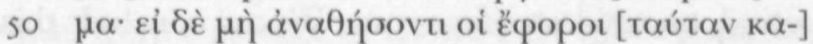

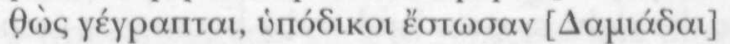

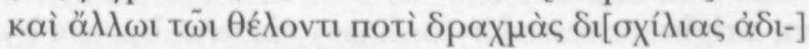

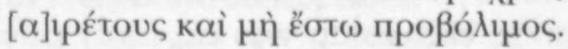

Whereas Damiadas ... the Lacedaimonian physician, (it) having been sent to him in writing as it has been voted, seeing that he came to us practicing the healing arts, that he showed himself second to no one in his skill as well as in excellence of life, awarded the greatest respect by our officials and city, that having labored as he was invited to by the people and having practiced his craft for two years among us, he did what was just to those in need, lacking nothing in zeal and concern about honor so as to treat equally all persons, both the needy and the rich, and slaves and freemen. And in staying and sojourning as resident alien, in what he had done he kept himself without offense, become worthy of the craft which he performed, and (worthy) of his own fatherland and of our city. And he kept himself without reproach in everything, behaving like a free man (liberally) toward all as befits a wise and educated man. And during (the magistracy of) Biadas in the month of Laphrios, seeing the city consternated because of income, he offered the people free of charge to render his physician's services for the rest of the year, exceeding in our regard the requirements of justice and giving a great demonstration of nobility and goodness and of kindness toward our polity. Because of these things, the people, showing gratitude to Damiadas for everything he had done, having been seized with benevolence regarding his being devoted to our city and performing every sort of good thing in (his) craft and in all (spheres of) life, has constituted him public guest and benefactor of our city. And let there be to him (the right to) possession (as alien) of land and a house and all other benevolence and honors which belong to the other public guests and benefactors of the city. The Ephoroi (overseers) during the magistracy of Biadas, inscribing this public guesthood upon a stone stele to be set up on the most conspicuous place of the agora, so that the city's benefac- 
torial memorial make manifest to all Damiadas' nobility-and-goodness and kindness. If the Ephoroi should not set it up as has been written, let them be subject to charges by Damiadas and by any other persons so wishing in amount of a lump sum of two-thousand drachmas and let it not be liable to court reversal.

The following remarks are pertinent here:

I. The invitation to a physician to settle in a city takes place by means of a vote in the council (line Io/I I epsaphisto). The city can also request another city (e.g., Cos, with its famous physicians' school) to send out a physician (e.g., I. Cret. IV I68, 2 I 8 B.C.), or a physician can apply himself (Xenophon, Mem. IV 2,5).

2. The appointed physician remained in the city that invited him for a contracted period, on resident alien terms. We can conclude this from line $4 \mathrm{I}$ where the right to own land and a house was granted to the physician, a right possessed by ordinary citizens, but not by aliens. At times, as a token of honor, citizenship was expressly offered to the physician at the end of his contracted period (I. Cret. I68, line 26).

3. Such contracts could be extended (cf. IG XII I, I032, c. 200 B. C., line 4 , from which it is evident that the physician Menokritos served the community for more than twenty years).

4. Obviously it was the contracted physician's obligation to provide medical care in the place where he settled not only to citizens, whether needy or wealthy, but also to other residents and foreigners (lines 19-20, cf. IG XII I, I032, line IO-I 5).

5. The physician was an employee (line i 5: ergolabesas). He received a determined salary. After long scholarly discussion about ancient physicians, there is general agreement on this score. What was involved was a basic salary, a guaranteed minimum income which the physician received exclusively because of the fact that he was available to the city. Beyond that, he could still ask for money in return for his services. ${ }^{23}$ The situation is comparable to that in remote Swiss mountain villages or on a small Dutch North Sea island such as Schiermonnikoog (population c. 800 ), where because the income from private practice alone would not provide sufficient support, a physician is also paid as community physician just to guarantee the availability of health care.

6. Inscriptions state of many city physicians that they worked free of charge (here line 30: dorean iatreusein). Here that probably means that Damiadas refrained from taking his basic stipend. However, that does

23. Fridolf Kudlien, Der griechische Arzt im Zeitalter des Hellenismus. Seine Stellung in Staat und Gesellschaft, Wiesbaden, Franz Steiner Verlag, 1979, pp. 52-64. 
not mean that he did not otherwise ask for payment for his treatments, yet that possibility is not excluded.

The reference to free care here puts us back on the trail of the fact, previously noted, that mention of payment was often suppressed for ideological reasons. A physician was a craftsman who had to live on what his craft would earn him, but in antiquity work for wages was considered to be of inferior worth, actually a form of slavery, compared with the ideal of the self-sufficient landowner who possessed wealth obtained through long-standing inheritance and who did not need to work for a living.

The ancient conception of the value of paid economic activity can be easily read from a passage of Cicero's De officiis (I 42, Loeb I 50-5I, pp. I 52-55), a work that traces back to Panaetius and thus also can be said to represent Hellenistic conceptions:

Now in regard to trades and other means of livelihood, which ones are to be considered becoming to a gentleman (Latin: liberalis; Greek: eleutherios) and which ones are vulgar, we have been taught, in general, as follows. ... Unbecoming to a gentleman (illiberales), too, and vulgar are the means of livelihood of all hired workmen whom we pay for mere manual labor, not for artistic skill. ... But the professions in which either a higher degree of intelligence is required or from which no small benefit to society is derived - medicine and architecture, for example, and teaching - these are proper for those whose social position they become. ... But of all the occupations by which gain is secured, none is better than agriculture, none more profitable, none more delightful, none more becoming to a freeman.

In other words, the artes ("crafts," Greek: technai) of healing, architecture, and teaching in the honorable disciplines (included are grammar, rhetoric, and philosophy) were respectable only if one exercised them as an amateur, not if one wanted to earn one's daily bread from them. ${ }^{24}$

What were the consequences of this mentality? Physicians who had higher aspirations put on the appearance of intellectuals, i.e., they took on the guise of rhetors in order to obscure the manual aspects of their discipline and to add another ideological layer over payment for their services. We find examples of this process of reinterpretation in the Damiadas inscription. The qualities of a rich benefactor (euergetes) are ascribed to the physician. He is friendly (line 25 : eleutherion, thus "as a

24. Cf. the discussion about other witnesses to the appraisal of different economic activities in M. M. Austin and P. Vidal-Naquet, Economic and Social History of Ancient Greece, Berkeley, California, University of California Press, 1977, pp. $11-18$ and 159-78. 
free man") as is befitting a wise and educated person (line 27: andri sophroni kai pepaideumenoi). He is generous, decent, and kind (lines 32-33: kalokagathias, eunoias, philostorgias). All these Greek words indicate typical aristocratic values. The honors that the physician receives for services rendered are called philanthropa (line 42 ). The word recalls the advice given by the Corpus Hippocraticum about payment and free treatment. The physician is advised not to begin his dealings with a patient by talking directly about payment but to speak of medical matters. The patient is not to be burdened with worries about payments so long as he is sick.

For should you begin by discussing fees, you will suggest to the patient either that you will go away and leave him if no agreement be reached, or that you will neglect him and not prescribe any immediate treatment. So one must not be anxious about fixing a fee. For I consider such a worry to be harmful to a troubled patient, particularly if the disease be acute. For the quickness of the disease, offering no opportunity for turning back, spurs on the good physician not to seek his profit but rather to lay hold on reputation. Therefore it is better to reproach a patient you have saved than to extort money from those who are at death's door (Parangeliai, Precepts, IV, Loeb pp. 316-17).

Besides such respectable medical reasons which, moreover, will further benefit the physician by bolstering his reputation, other reasons are at work here. In Precepts VI the physician is advised to assess the costs of his services according to the financial capacity of his patients.

VI. I urge you not to be too unkind, but to consider carefully your patient's superabundance or means. Sometimes give your services for nothing, calling to mind a previous benefaction or (your) present reputation. And if there be an opportunity of serving one who is a stranger in financial straits, give full assistance to all such. For where there is love of man, there is also love of the art. For some patients, though conscious that their condition is perilous, recover their health simply through their contentment with the goodness of the physician. And it is well to superintend the sick to make them well, to care for the healthy to keep them well, but also to care for one's self, so as to observe what is seemly (Precepts, VI, Loeb pp. 318-19).

In other words, if the physician is benevolent and friendly towards his patients, the patients in turn will show benevolence toward the healing arts and express their gratitude to the noble physician by paying. ${ }^{25}$ Pay-

25. Cf. Nutton, (n. 2I) "Continuity." 
ment, however, is not referred to by the ordinary word misthos, but rather by philanthropon: a gift, a service done to a friend.

Free care in certain instances fits this framework exactly. Such free care can have positive propaganda effect. The physician must enjoy a certain popularity in order to obtain his employment as city physician as well as to keep it and possibly receive some extras, such as citizenship.

The word philanthropia therefore reflects a totally different mentality than that expressed by the modern term, "philanthropy." Philanthropia was not based on any sort of humanitarian ideal, on human worthiness or "human rights," but rather on the principle of benefaction and reciprocity, the performance of some benefaction by a rich benefactor on behalf of the citizenry in the justified expectation of political prestige. "They would not pay, but they would give." ${ }^{26}$ Furthermore, it is by no means obvious that the free care mentioned was to the particular benefit of the neediest members of the community. On the contrary, benefaction in antiquity was directed to the citizenry in general, not to some determined social stratum. ${ }^{27}$

The ancient physician always strived to improve the ambiguous status of his discipline. On the one hand it was a craft, and on the other, an intellectual discipline, with a salutary purpose. Yet medicine was never able to find a respectable place among the artes liberales, even by connecting up with philosophy which stood higher than the artes liberales. The very title of one of Galen's writings speaks volumes: The Best Physician Is Likewise a Philosopher, Hoti ho aristos iatros kai philosophos. In that writing he contends that it is benefaction toward the community (euergesia) and not financial gain that should be the proper goal and motive of the art of healing.

In an autobiographical fragment, Galen maintains that he himself never asked for payment for his services. ${ }^{28}$ Whether he ever accepted any payment is a different question. For elsewhere it seems that Galen did indeed accept payment. For instance, he took four hundred gold pieces for his treatment of a rich senator's wife (De Praecognitione XIV 647 ed.

26. William W. Tarn, Hellenistic Civilization, and ed., London, E. Amold and Co., 1930, p. 100. Here Tarn offers a much too idealistic picture of the Hellenistic physician, to which I do not subscribe.

27. Cf. for an extensive treatment of the phenomenon of benefaction, Paul Veyne, Le pain et le cirque, Paris, Seuil, I976.

28. Fridolf Kudlien, "Medicine as a 'Liberal Art' and the Question of the Physician's Income," $J$. Hist. Med. 31: 453 ff., 1976, and his "Die Unschätzbarkeit ärztlicher Leistung und das Honorarproblem," Medizinisch-Historisches Journal 14: 3-16, 1979. 
Kühn). However the way in which payment took place differed notably from the way in which less highly esteemed services were remunerated. First of all, payment was not asked for. If payment occurred, then it was quite honorable (honestus) since it took the form of an honorarium, a term still in use today. There was no direct compensation for services rendered, but rather a honorable financial gratuity. The connotation of such a transaction is that the value of the service performed cannot really be expressed in terms of money.

Chrysippus explains that a philosopher might accept payment for his instructions and even ask for such payment so long as he avoided the impression of excessive greed. The physician in turn, in his endeavor to attain as high a standing for his profession as possible and to rid it of its craftsmanlike image, sought to link up with this ideology (see Corpus Hippocraticum, Precepts IV and VI).

The ancient concept of liberalitas and Christian ethics ("It is more blessed to give than to receive," Acts 20:35) are the roots of the modern physician's ambiguous attitude about the honorarium for his work.

Many physicians were probably quite satisfied with their status of craftsman. But those who aspired to conceive of themselves in a rather scholarly role put on the philosopher's mantle and adopted the language and lifestyle of the elite benefactor.

\section{THE PHYSICIAN AND THE NATURAL SCIENCES}

It has often been pointed out that when compared with the arts, letters, and social sciences, the natural sciences experienced far less good fortune in antiquity. ${ }^{29}$ The relative stagnation of the natural sciences in antiquity applied both to anatomy and biology as well as to all other experimental sciences that might have contributed significantly to the progress of medical knowledge. Experimentation looked too much like the manual labor of the craftsman, hence fell outside the field of vision of the physician who considered himself a person of learning. The great exception confirming this rule was the flourishing Alexandrian school of Herophilus and Erasistratus of the third century B.c. ${ }^{30}$

29. Cf. H. W. Pleket, "Technology and Society in the Greco-Roman World," Acta Historiae Neerlandica 2: $\mathrm{I}-2$ 5, 1967 , further elaborated in "Technology in the Greco-Roman World: A General Report," TALANTA 5: 6-47, 1973, and M. A. Wes, Tussen polis en technopolis, Leiden, E. J. Brill, 1974 .

30. H.F.J. Horstmanshoff, "Sectie en anatomie in Alexandrië," Hermeneus 57: 142-51, 1985. 


\section{CONCLUSION}

Physicians of antiquity simply did not possess the scientific training, scholarly attitudes, and social standing which we are anachronistically inclined to ascribe to them. Generally speaking, any connection of the scholarly or scientific with the empiric remained foreign to them. Their intellectual aspirations moved rather in the direction of philosophy and rhetoric. Given the prevailing social and economic mentality of antiquity, the status and prestige of these disciplines were higher and greater than those of the art of healing and other related sciences. The physicians of antiquity were primarily craftsmen. If they sought to appear as "men of learning," then it was rather as philosophers or rhetors than as naturalists or field biologists: ietros gar philosophos isotheos (Corpus Hippocraticum, De decenti habitu 5).

Department of Ancient History

University of Leiden

P.O. Box 9515

2300 RA Leiden, The Netherlands 


\section{ARTS EN PATIEN}

Athene, 400 v. Chr.; twee artsen di nu 'dood' genoemd wordt. Enkele v asthma ... epidèmiè... pleuritis . . Al deze termen behoren tot het norr eeuwen die ons van de Griekse gene stand die ons van bijvoorbeeld de Vo We herkennen onze westerse manie Die herkenning kan echter bedrieglij en 'epidèmiè' niet hetzelfde als wij. een Galenus? Waren er in de Grieks-1 ziekenhuizen kunt vergelijken? Was

Een praktijkgeval uit de Epidemieën De titel van één van de geschriften di mieën, vrij vertaald: 'Ziektegeschieder v. Chr.) is zeer weinig bekend. Er is verd, maar geen van die medische ge zelf worden toegeschreven. Waarschi bibliotheek die gebruikt werd op de $\mathrm{m}$ schillende auteurs is bijgedragen. Eé het volgende geval:

Een jongeman komt het iatreion (de jaap over zijn neus, gevolg van een sto potscherf heeft geraakt. De iatros (art met een spons en stroken schoon, drc naald, hecht de wond en strooit er een legt hij er een compres op: een dubbel schone spons en een handvol bladerer door een kunstig aangelegd verband naald en draad. Bij dat verband staan v schappelijke positie van de arts en ove

\section{Gemeente-artsen en particuliere artsen}

Elders in de Hippocratische geschrifter spectaculaire verbanden moet leggen, niet is gediend. Blijkbaar was de conc niets na om indruk te maken. Een kunst nodig was, wilde de arts een positie als . ven. Daarover moest namelijk de volks' voor spectaculaire verbanden, voor een $\mathrm{i}$ voor succes bij de behandeling en een gers. Menige arts wordt in een ere-inscrif rarium en in moeilijke omstandigheden, post bleef.

De betrekking van gemeente-arts was ge verzekerde van een vast minimum-inkom wél een honorarium kon vragen en, bo artsen heeft de gehele oudheid door best in grote delen van Europa tot diep in de

\section{EID}

I in een taal die 1a.... crisis ...

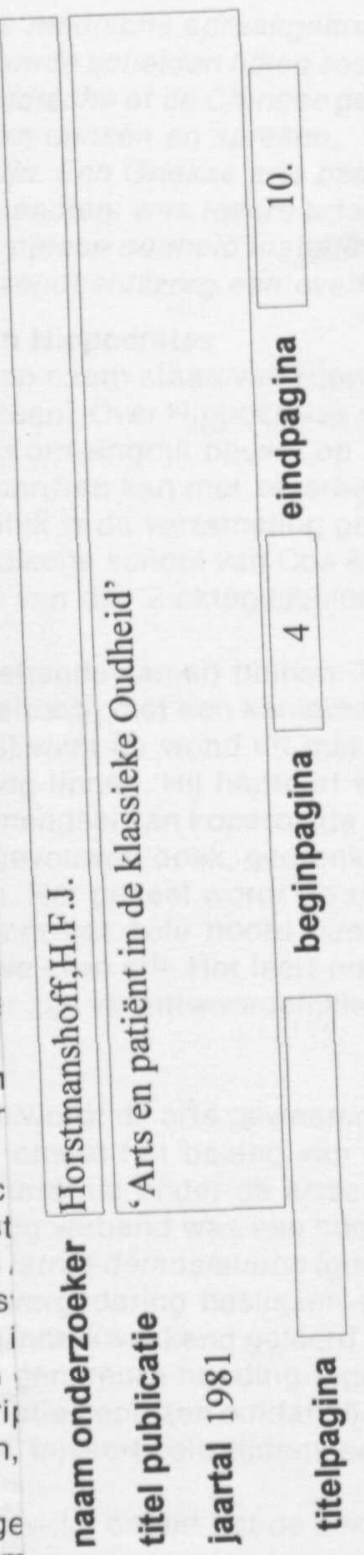

kan vandaag. De korter dan de afskunde scheidt.

de met 'rheuma'

Hippocrates of die je met onze staak?

tes luidt Epideos (ca. 460-380 haam overgelean Hippocrates iften een soort araan door versen' beschrijft

eft een lelijke hem met een wijn, dept dan g een bronzen ning over. Dan ijn, een stukje ats gehouden tgenaaid met over de maatsef.

dat hij niet te iënt daarmee t en lieten zij ame, die hard -arts) verwerwas gevoelig , maar vooral de arme buran een honoemie, op zijn

an de functie $\mathrm{n}$ van wie hij n gemeentezijn te vinden in de arts op 


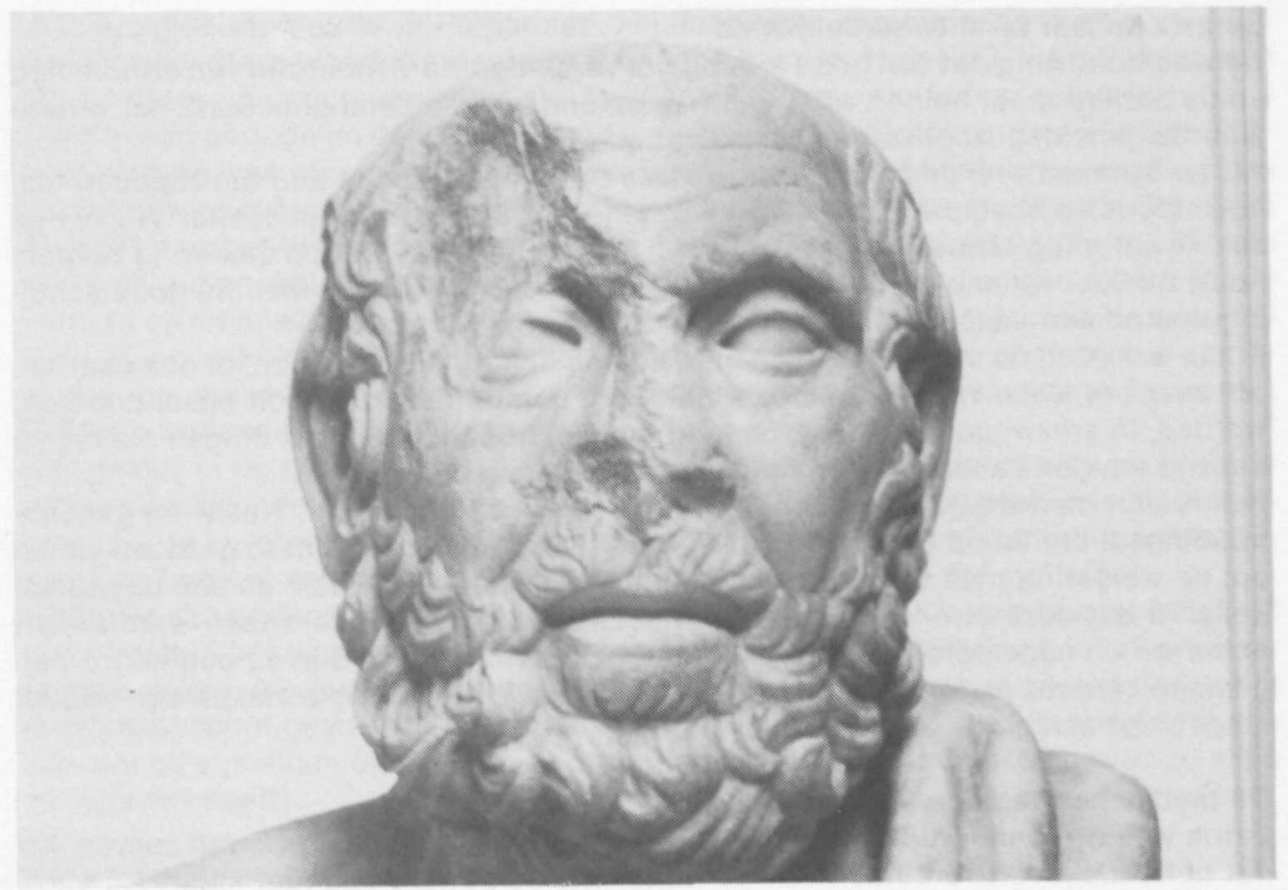

Hippocrates

bijvoorbeeld Schiermonnikoog, waar het geringe aantal patiënten een vrije vestiging zou verhinderen zodat de overheid een arts aantrekt tegen een gegarandeerd basisinkomen, is hiermee goed vergelijkbaar.

De arts verplichtte zich gedurende de looptijd van zijn contract in de polis zijn praktijk uit te oefenen. Zijn basisinkomen werd betaald uit de opbrengst van het iatrikon, een belasting voor alle burgers die soms in natura werd afgedragen. Er is wel gesuggereerd dat in het klassieke Griekenland en in het Ptolemaeïsche Egypte al een door de overheid georganiseerde gezondheidszorg, een soort ziekenfonds, zou hebben bestaan. Voor een gezondheidszorg als systeem van sociale verzekering, dus met recht op gratis behandeling voor alle betalers van het iatrikon, is echter geen bewijs te vinden.

De arts die zich in een bepaalde polis vestigde richtte een iatreion in, liefst in het centrum van de stad. In de Hippocratische geschriften worden precieze regels gegeven voor de inrichting van zo'n iatreion.

In uitzonderingsgevallen zal een patiënt eens enkele dagen ter observatie in het iatreion zijn opgenomen, meestal bezocht de arts de zieken echter thuis. Het iatreion fungeerde dus als polikliniek en is zeker niet met ons ziekenhuis te vergelijken.

De Hippocratische artsen vormden overigens een minderheid. Daar er geen erkende opleidingen en beschermde titels waren, kon iedereen zich vrij vestigen. Een groot deel van de antieke artsen zal hebben bestaan uit rondreizende avonturiers. Uit grafinscripties van artsen weten we dat zij in Hellenistisch-Romeinse tijd 'de stromen van de Okeanos' en 'de grenzen van Europa, Afrika en het grote Azië' hebben aanschouwd. Sommige artsen kwamen tot hoog aanzien en drongen door tot hofkringen, de meesten echter leefden als vrije handwerkslieden, gerespecteerd, maar mede door hun zwervende leefwijze vaak zonder burgerrecht. 


\section{ARTS EN PATIENT IN DE OUDHEID}

Athene, 400 v. Chr.; twee artsen discussiëren over hun patiënten in een taal die nu 'dood' genoemd wordt. Enkele woorden vangen we op: 'rheuma . . crisis ... asthma ... epidèmiè ... pleuritis ...'

Al deze termen behoren tot het normale medische spraakgebruik van vandaag. De eeuwen die ons van de Griekse geneeskunde scheiden lijken zoveel korter dan de afstand die ons van bijvoorbeeld de Voorindische of de Chinese geneeskunde scheidt. We herkennen onze westerse manier van denken en spreken.

Die herkenning kan echter bedrieglijk zijn. Een Griekse arts bedoelde met 'rheuma' en 'epidèmiè' niet hetzelfde als wij. Bovendien: was iedere arts een Hippocrates of een Galenus? Waren er in de Grieks-Romeinse oudheid instellingen die je met onze ziekenhuizen kunt vergelijken? Was gezondheidszorg een overheidstaak?

\section{Een praktijkgeval uit de Epidemieën van Hippocrates}

De titel van één van de geschriften die op naam staan van Hippocrates luidt Epidemieën, vrij vertaald: 'Ziektegeschiedenissen'. Over Hippocrates van Cos (ca. 460-380 v. Chr.) is zeer weinig bekend. Er is een omvangrijk oeuvre op zijn naam overgeleverd, maar geen van die medische geschriften kan met zekerheid aan Hippocrates zelf worden toegeschreven. Waarschijnlijk is de verzameling geschriften een soort bibliotheek die gebruikt werd op de medische school van Cos en waaraan door verschillende auteurs is bijgedragen. Eén van die 'Ziektegeschiedenissen' beschrijft het volgende geval:

Een jongeman komt het iatreion (de behandelkamer) binnen. Hij heeft een lelijke jaap over zijn neus, gevolg van een stoeipartij met een kameraad, die hem met een potscherf heeft geraakt. De iatros (arts) wast de wond uit met veel wijn, dept dan met een spons en stroken schoon, droog linnen. Hij hanteert vaardig een bronzen naald, hecht de wond en strooit er een mengsel van koperoxide en honing over. Dan legt hij er een compres op: een dubbelgevouwen doek, gedrenkt in wijn, een stukje schone spons en een handvol bladeren. Het geheel wordt op zijn plaats gehouden door een kunstig aangelegd verband om het hele hoofd heen, vastgenaaid met naald en draad. Bij dat verband staan we even stil. Het leert ons iets over de maatschappelijke positie van de arts en over zijn verantwoordelijkheidsbesef.

\section{Gemeente-artsen en particuliere artsen}

Elders in de Hippocratische geschriften wordt de arts gewaarschuwd dat hij niet te spectaculaire verbanden moet leggen, omdat het belang van de patiënt daarmee niet is gediend. Blijkbaar was de concurrentie onder de artsen groot en lieten zij niets na om indruk te maken. Een kunstig verband was een soort reclame, die hard nodig was, wilde de arts een positie als iatros demosieuoon (gemeente-arts) verwerven. Daarover moest namelijk de volksvergadering beslissen en die was gevoelig voor spectaculaire verbanden, voor een indrukwekkend geleerd betoog, maar vooral voor succes bij de behandeling en een genereuze houding tegenover de arme burgers. Menige arts wordt in een ere-inscriptie geprezen omdat hij afzag van een honorarium en in moeilijke omstandigheden, bijvoorbeeld tijdens een epidemie, op zijn post bleef.

De betrekking van gemeente-arts was gewild, omdat het de bekleder van de functie verzekerde van een vast minimum-inkomen, een toevloed van patiënten van wie hij wél een honorarium kon vragen en, bovenal, status. Dit instituut van gemeenteartsen heeft de gehele oudheid door bestaan. Soortgelijke instellingen zijn te vinden in grote delen van Europa tot diep in de achttiende eeuw. De positie van de arts op 


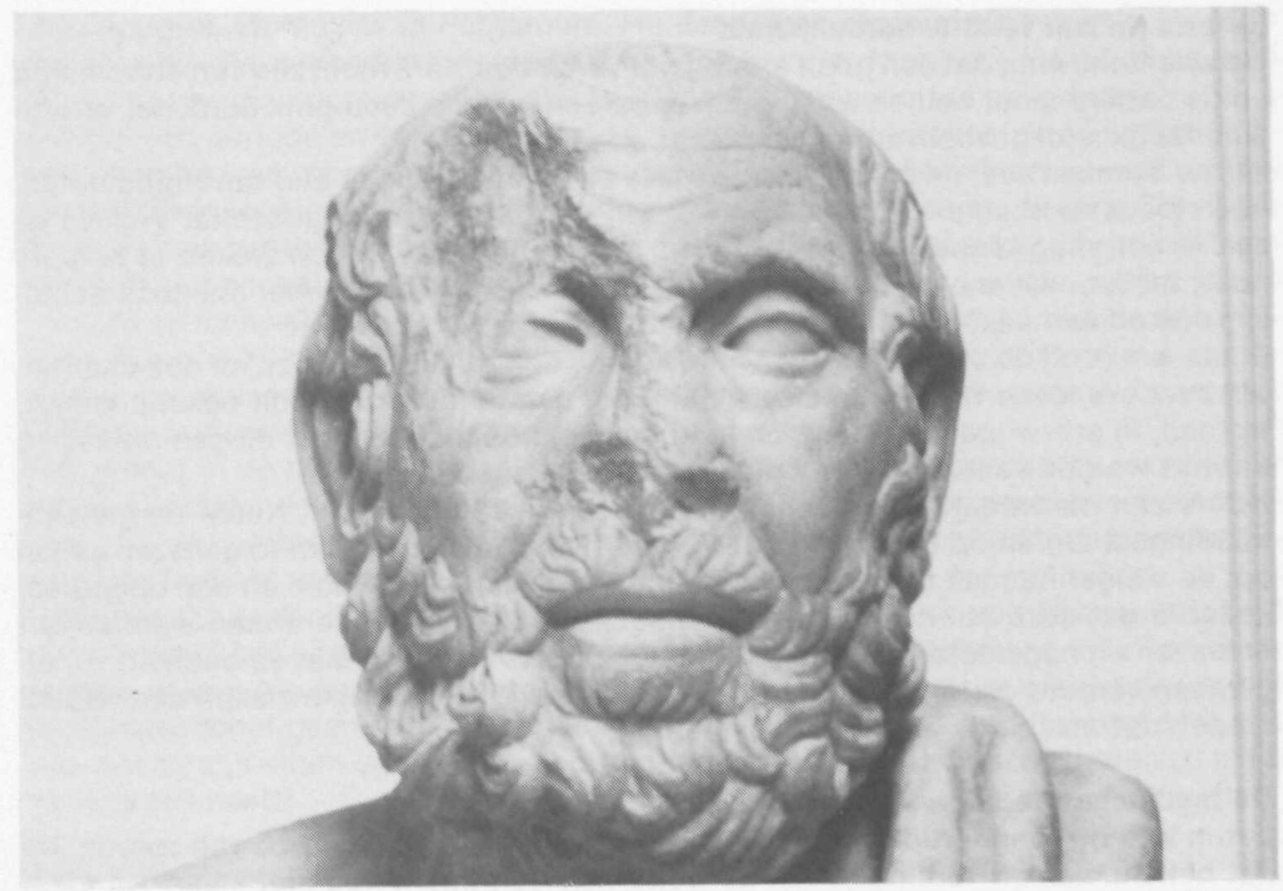

Hippocrates

bijvoorbeeld Schiermonnikoog, waar het geringe aantal patiënten een vrije vestiging zou verhinderen zodat de overheid een arts aantrekt tegen een gegarandeerd basisinkomen, is hiermee goed vergelijkbaar.

De arts verplichtte zich gedurende de looptijd van zijn contract in de polis zijn praktijk uit te oefenen. Zijn basisinkomen werd betaald uit de opbrengst van het iatrikon, een belasting voor alle burgers die soms in natura werd afgedragen. Er is wel gesuggereerd dat in het klassieke Griekenland en in het Ptolemaeïsche Egypte al een door de overheid georganiseerde gezondheidszorg, een soort ziekenfonds, zou hebben bestaan. Voor een gezondheidszorg als systeem van sociale verzekering, dus met recht op gratis behandeling voor alle betalers van het iatrikon, is echter geen bewijs te vinden.

De arts die zich in een bepaalde polis vestigde richtte een iatreion in, liefst in het centrum van de stad. In de Hippocratische geschriften worden precieze regels gegeven voor de inrichting van zo'n iatreion.

In uitzonderingsgevallen zal een patiënt eens enkele dagen ter observatie in het iatreion zijn opgenomen, meestal bezocht de arts de zieken echter thuis. Het iatreion fungeerde dus als polikliniek en is zeker niet met ons ziekenhuis te vergelijken.

De Hippocratische artsen vormden overigens een minderheid. Daar er geen erkende opleidingen en beschermde titels waren, kon iedereen zich vrij vestigen. Een groot deel van de antieke artsen zal hebben bestaan uit rondreizende avonturiers. Uit grafinscripties van artsen weten we dat zij in Hellenistisch-Romeinse tijd 'de stromen van de Okeanos' en 'de grenzen van Europa, Afrika en het grote Azië' hebben aanschouwd. Sommige artsen kwamen tot hoog aanzien en drongen door tot hofkringen, de meesten echter leefden als vrije handwerkslieden, gerespecteerd, maar mede door hun zwervende leefwijze vaak zonder burgerrecht. 


\section{De arts en zijn verantwoordelijkheid}

De waarschuwing dat een goed arts bij het verbinden wars moet zijn van effectbejag en de patiënt moet helpen wijst ons nog op een tweede belangrijk punt: het verantwoordelijkheidsgevoel van de Hippocratische arts.

Als we spreken over de plichten van de arts denkt ieder aan de Eed van Hippocrates, nog steeds voorbeeld voor de huidige artseneed. Hier volgt een gedeelte: 'Welke huizen ik ook mag binnengaan, ik zal er alleen binnengaan om de zieken te helpen; nooit zal ik er willens en wetens enig onrecht doen, in het bijzonder mij nooit schuldig maken aan sexuele omgang met man of vrouw, vrije of slaaf.

Ik zal, wat ik bij de uitoefening van mijn beroep ook zal horen of zien, of ook daarbuiten over het leven van mensen te weten kom aan dingen, die nooit bekend mogen worden, in stilzwijgen bewaren, en het beginsel hooghouden, dat dingen die mij zò bekend worden vallen onder de plicht van geheimhouding'.

Het is een merkwaardig en moeilijk te interpreteren document. Naast de geheimhoudingsplicht en de belofte de kennis aan te zullen wenden om te genezen vallen op: de weigering mee te werken aan vruchtafdrijving, euthanasie en alle operaties. Zeker is dat deze strenge erecode niet door alle praktizerende artsen werd onderschreven en nageleefd. Abortus provocatus bijvoorbeeld werd in de oudheid vrij algemeen verricht en het was niet uitzonderlijk dat ongeneeslijke zieken een middel kregen dat een einde aan hun lijden maakte.

\section{De medische theorie en de praktijk}

Laten we nog even terugkeren naar de behandelkamer van de iatros van zoëven. $\mathrm{Na}$ het behandelen en verbinden van de wond was de patiënt nog niet klaar! Hij moet 'reinigende' medicijnen drinken om te voorkomen dat de wond weer open zal gaan en krijgt een streng dieet opgelegd: vooral geen kaas! Kaas immers is flegmatisch (Grieks phlegma: slijm) en veroorzaakt zweren.

Een vierde eeuws arts, opgeleid in de Hippocratische school, kon zeer nauwkeurig waarnemen. Hij luistert met zijn oor tegen de rug van de patiënt naar diens ademhaling. Hij voelt de temperatuur van de verschillende lichaamsdelen en betast de buik. Hij ruikt de geur van allerlei afscheidingen: stoelgang, urine, slijm, braaksel, controleert de kleur en moet volgens sommige Hippocratische geschriften zelfs de smaak ervan proeven, waarvoor enige zelfoverwinning nodig geweest zal zijn!

De theoretische achtergrond van dit alles is de leer van de lichaamssappen (Latijn: humores): slijm, zwarte gal, bloed en gele gal. Ziekte treedt op als een verkeerde menging (Latijn: temperamentum) tussen de lichaamssappen aanwezig is. Symptomen daarvan zijn allerlei afscheidingen, zoals urine, zweet en dergelijke. Deze verstoring kon het gevolg zijn van een verkeerde leefwijze (Grieks: diaitè, diset).

De arts tracht door zijn behandeling het juiste evenwicht te herstellen.

\section{Experimenten, sectie en anatomie}

Al was de observatie van individuele ziektegevallen nog zo nauwkeurig, toch heeft het achterwege laten van experimenten en het ontbreken van kennis van de natuurwetten de verdere ontwikkeling van de geneeskunde ernstig belemmerd.

Men heeft wel gezegd dat de Griekse filosofen de natuur trachten te verklaren met hun ogen dicht. Dat geldt dan ook voor de medici, die vaak tevens filosofen waren. Zij bespiegelden liever dan dat zij systematisch experimenteerden en stelden zich tevreden met het materiaal dat de natuur 'vanzelf' aanbood.

Dit blijkt ook bij de anatomie. Men bestudeerde liever de anatomie door de wonden als 'vensters' te gebruiken dan dat men sectie verrichtte. Zo werkte Galenus (ca. 130-200 n.Chr.), de invloedrijkste arts uit de gehele oudheid na Hippocrates, jaren- 
lang als gladiatorenarts in Pergamum. Hij deed daar anatomische kennis op doordat hij zulke diepe wonden moest behandelen. Elders in de antieke literatuur worden slachtoffers van roofovervallen als studieobject voor anatomen genoemd. $\mathrm{Er}$ is slechts één periode en één plaats aan te wijzen waar het intellectuele klimaat blijkbaar gunstig was voor verder onderzoek op het terrein van de natuurwetenschappen en de anatomie: Alexandrië van de derde eeuw v.Chr. tot de eerste eeuw n.Chr. Deze door Grieken gestichte en beheerste stad werd in de Hellenistische tijd een centrum van kunsten en wetenschappen. Volgens de overlevering werd er niet alleen sectie verricht op menselijke lijken, maar zelfs vivisectie op ter dood veroordeelde misdadigers. Noch voor, noch na de bloeiperiode van de Alexandrijnse anatomie is echter sectie op menselijke lichamen systematisch en op grotere schaal beoefend. Galenus ontleedde alleen dieren.

Het geloof in de autoriteit van Galenus, bewonderaar van Hippocrates, vruchtbaar auteur (22 dikke delen zijn overgeleverd, tweederde van wat hij totaal heeft geschreven) zou de verdere ontwikkeling van de geneeskunde vijftienhonderd jaar blokkeren. Een berucht voorbeeld is zijn theorie over de beweging van het bloed.

Ondanks zijn ontleedkundige onderzoekingen bleef hij uitgaan van de aanwezigheid van poriën in het harttussenschot om het bloed van de rechter- naar de linkerkamer te laten gaan. Als de grote anatoom Vesalius in 1543 vast moet stellen dat in het harttussenschot geen poriën te vinden zijn, heeft Galenus hem echter nog zo in zijn ban dat hij zijn eigen ogen niet gelooft: hij prijst God omdat deze de poriën zo klein geschapen heeft!

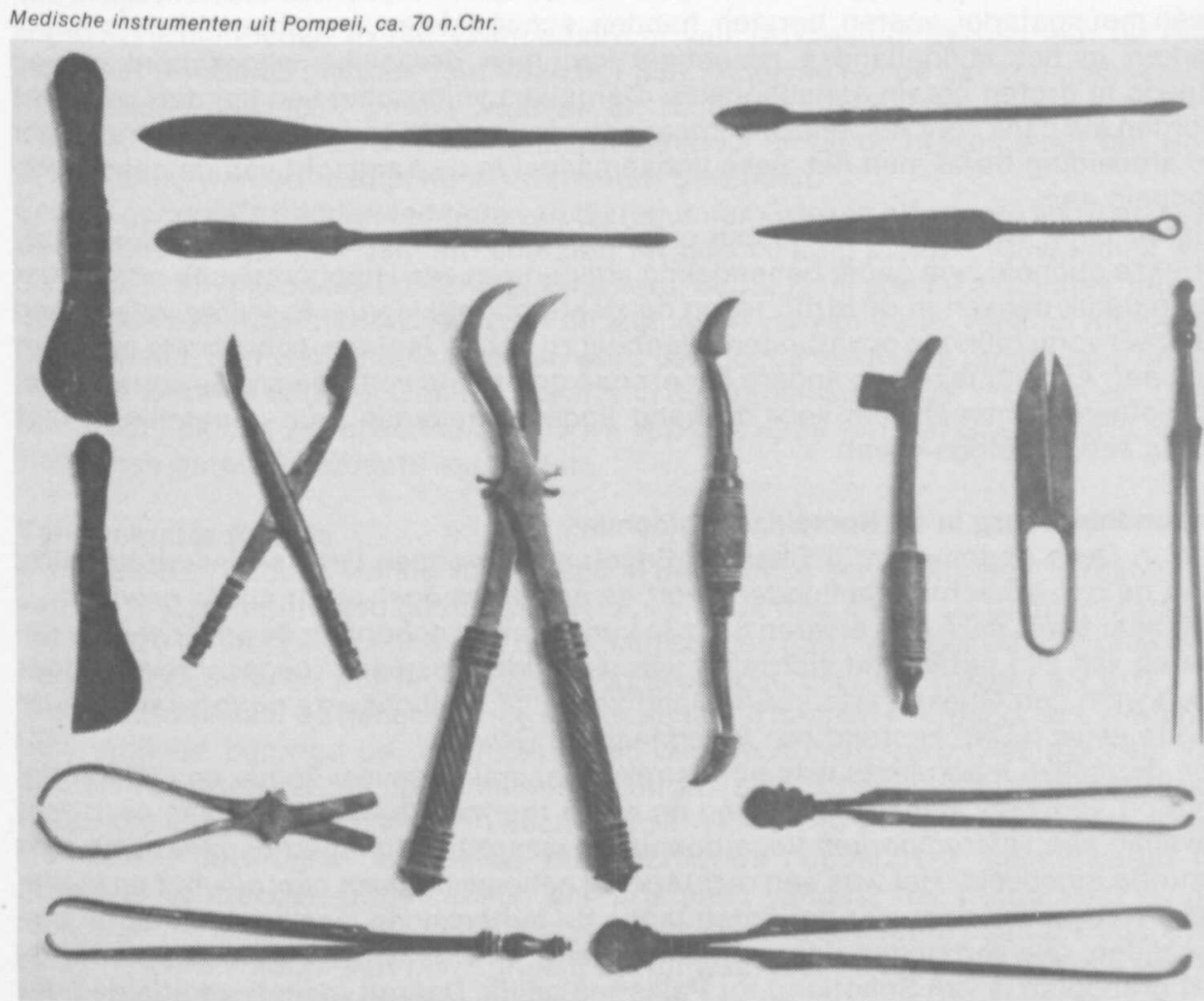




\section{Wonderbaarlijke genezingen}

'Hermon uit Thasos. Hij was blind en de god genas hem. Toen hij echter nadien de god zijn beloning onthield, maakte deze hem weer blind. Toen hij weer binnen kwam slapen maakte de god hem gezond'. Dit is één van de vele als inscriptie overgeleverde wondergenezingen van Epidaurus. De heiligdommen van Asclepius in Epidaurus, Pergamum en Cos zijn in de oudheid uitgegroeid tot omvangrijke klinieken en hospitalen. Daar werd de tempelslaap toegepast. Verlamden, kreupelen, blinden, kaalhoofdigen, zwangere vrouwen, allen zochten genezing en verlossing bij de heilbrengende god. De bedevaartgangers hulden zich in de huiden van de geofferde dierenen zochten een plekje op de vloer van de uitgestrekte lighallen. In hun droom verscheen dan de bebaarde Asclepius met de slangestaf. Soms genas hij onmiddellijk door handoplegging of chirurgische ingreep, vaker gaf hij aanwijzingen over de weg die men moest volgen om genezing te bereiken: gebruik van kruiden, zwemmen, mentale training en dergelijke. Suggestie moet hier een belangrijke en, als we de opgetekende gevallen mogen geloven, vaak doeltreffende rol hebben gespeeld.

De invloed van de Asclepieia bleef groot tot diep in christelijke tijd. Zij vervulden stellig een sociale functie. Armen en behoeftigen hadden vrij toegang en kregen ook onderdak. Met ziekenhuizen kan men dergelijke inrichtingen echter niet vergelijken. In klassieke tijd waren er geen artsen aan de Asclepieia verbonden, alleen droomuitleggers. Behandeling vond dan ook niet in het heiligdom plaats.

Ook de heiligdommen van andere goden, vaak van plaatselijke betekenis, waren centra waar men genezing kwam zoeken. Antieke tempels en gewijde plaatsen waren overladen met wijgeschenken, vaak in de vorm van lichaamsdelen, zoals een been met spatader, voeten, borsten, handen, schaamdelen, gezichten. In christelijke kerken in het Middellandse zeegebied kan men dergelijke wijgeschenken nog steeds in groten getale aanschouwen. Dergelijke wijgeschenken konden gebracht worden als dank voor de genezing, maar ook als bede om genezing, dus vooraf. Door de afbeelding beval men het zieke lichaamsdeel in de aandacht van de genezende godheid aan.

Hieruit blijkt wel dat het volkomen onjuist zou zijn te menen dat alle zieken in de Griekse oudheid zich onder behandeling stelden van een Hippocratische arts en dat het redelijk denken in de strijd tegen de ziekte hoogtij vierde. Er waren vele artsen van zeer verschillende opvattingen. Wanneer zij echter faalden, schroomde men niet zich aan Asclepius of een andere genezende god toe te vertrouwen. Gewone artsen accepteerden immers om voor de hand liggende redenen (hun aanstelling!) niet graag een hopeloos geval.

\section{Gezondheidszorg in de Romeinse legioenen}

Een in Deva (tegenwoordig Chester, Engeland) gevonden Griekse inscriptie luidt: 'Aan de oppermachtige heilgoden heeft de arts Hermogenes dit altaar gewijd'.

Blijkbaar heeft deze arts ervaren dat zijn kunde tekort schoot en de onverwachte genezing van zijn patiënt (of zichzelf?) aan de reddende goden toegeschreven. Maar hoe kwam een Griekse arts in Engeland verzeild? Wellicht was hij legerarts. In de eerste eeuw n.Chr. bestond een legerplaats te Deva.

Een dergelijke legerplaats was uitgestrekt, meestal ongeveer $25 \mathrm{ha}$. en van allerlei comfort voorzien. Behalve barakken en eigen thermen (badruimten) was er in veel gevallen een valetudinarium (legerhospitaal, lazaret). Zo'n legerhospitaal was zeer venuftig ingedeeld. Het was een rechthoekig gebouw met een centrale hof en kleine ziekenvertrekken voor vier patiënten langs de buitenzijden, vaak ook langs de binnenzijden, alle verbonden door een lange gang. Er was een aparte operatieruimte. Het grondplan is van Schotland tot Palestina gelijk. Daaruit mogen we afleiden dat 


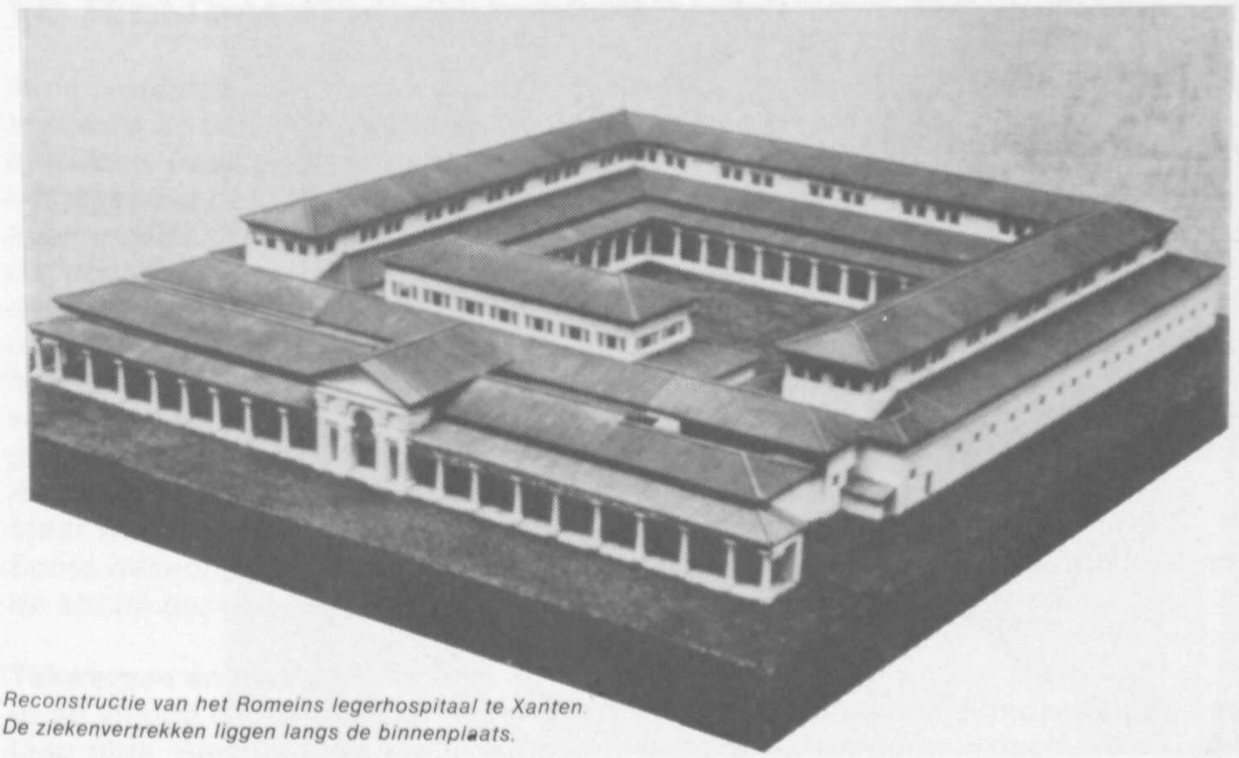

er een goed georganiseerde militaire geneeskundige dienst bestond in de Romeinse keizertijd.

Graafwerkzaamheden in het valetudinarium van Novaesium (Neuss aan de Rijn) brachten verkoolde plantenresten aan het licht. Analyse leerde dat er geneeskrachtige kruiden gevonden waren, waarvan uit Romeinse medische literatuur bekend was dat zij werden gebruikt als kalmeringsmiddel en bij de behandeling van wonden. Vlakbij werden medische instrumenten gevonden.

Enkele generaals hadden ten tijde van de republiek Griekse lijfartsen die zij met een welwillend gebaar ook aan hun soldaten ter beschikking stelden. Gewoonlijk werden zieken en gewonden echter ingekwartierd, oudtijds bij adellijke families, later in bevriende naburige steden. Pas toen de legioenen ver van Italië, vaak op afgelegen grensposten hun werk moesten doen, werd een goede medische organisatie onontbeerlijk. Zeker is dat veel Grieken als arts in de Romeinse legioenen dienden. Daarom is het ook niet zo verwonderlijk als wij een inscriptie van een Griekse arts in een Romeinse garnizoensplaats aantreffen.

\section{Van archiater tot arts}

De Romeinen hadden weinig vertrouwen in de Griekse geneeskunde. De resultaten van de artsen rechtvaardigden dat vertrouwen ook niet altijd. De dichter Martialis (ca. 40-120 n.Chr.) bespot een arts die weinig succes had: 'Vroeger was Diaulus arts, nu is hij doodgraver: wat hij nu als doodgraver doet, deed hij vroeger als arts'.

Toen de Romeinen de geneeskunde echter eenmaal hadden overgenomen, werd hun belangrijkste bijdrage de organisatie van de gezondheidszorg. Het systeem van gemeente-artsen pasten de Romeinen op uitgebreide schaal toe. In iedere stad van enige omvang waren sinds de tweede eeuw n.Chr. één of meer gemeente-artsen werkzaam. Zij kregen de Griekse titel archiatros ('opperarts'), gelatiniseerd tot archiater of arciater, uitgesproken als 'artsjater', vandaar het Duitse Arzt en het Nederlandse arts. De gemeente-artsen hadden een bevoorrechte positie en genoten onder andere vrijdom van belastingen, in ruil waarvoor zij de arme burgers van de stad kostenloos moesten behandelen. 


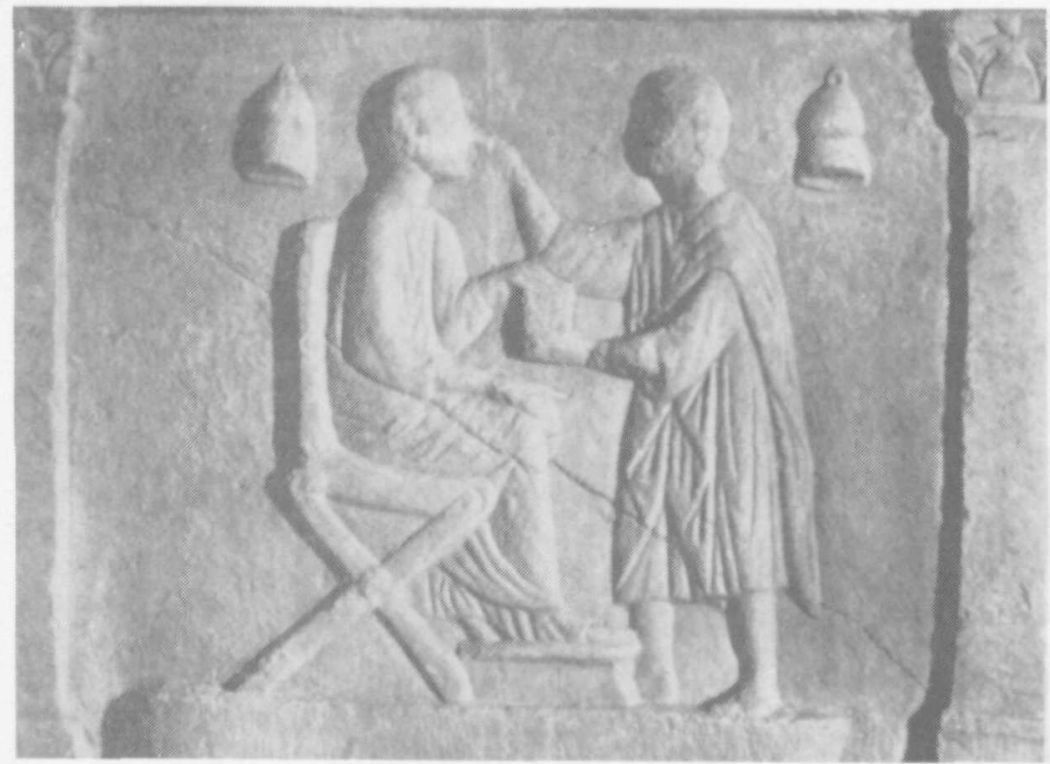

Een oogarts brengt een zalf aan.

\section{Angst en bijgeloof}

Het dagelijks leven in de oudheid was doortrokken van angst en onzekerheid. Tegen natuurrampen en ziekten baatte menselijke hulp nauwelijks. Erg veel effect kan de medische zorg niet gehad hebben. Bij werkelijke grote rampen, zoals epidemieën, werden orakels geraadpleegd, offers gebracht, zondebokken gevonden en heengezonden of gedood, uitheemse culten ingevoerd. Al deze reacties kwamen niet voort uit het zoeken naar een doeltreffend antwoord, maar uit de zekerheid van het kennen van de oorzaak van de ziekte: goddelijke toorn, opgewekt door menselijk gedrag. Een blikseminslag, een zwetend godenbeeld, een kalf met twee koppen, een overstroming, alles werd gezien als een teken van de toorn van de goden die zich ontlaadde in ziekte en onheil.

Als je plotseling koorts kreeg kon je ook het slachtoffer zijn van een demonische wraakoefening, afgeroepen door een persoonlijke vijand. Een vervloeking werd op een loden plaatje geschreven, voorzien van de naam van de gehate persoon, en bijvoorbeeld in een waterput geworpen. Wanneer iemand ten prooi viel aan een slopende ziekte, ging de verdenking onmiddellijk in de richting van magie, hekserij of vergiftiging.

Als we dit alles bedenken is het een wonder dat de antieke geneeskunde desalniettemin een hoog peil heeft weten te bereiken en zich aan de kluisters van het bijgeloof heeft ontworsteld. De wetenschappelijke grondslag van de geneeskunde, de behoefte aan ethische verantwoording en de organisatie van de gemeente-artsen vormen de belangrijkste bijdrage van Grieken en Romeinen aan de zorg voor de zieke mens.

\section{H. F. J. Horstmanshoff}

\section{literatuur:}

Verantwoord en boeiend is: Guido Majno, The healing hand, Cambridge, (Mass.) 1975 met schitterende illustraties. Een goed overzicht geeft H. M. Koelbing. Arzt und Patient in der antiken Welt, Zürich 1977.

L. Elaut, Antieke geneeskunde, Antwerpen-Amsterdam 1960, biedt een verzameling bronnen in Nederlandse vertaling. 